\title{
A review of the genus Microcrambus Błeszyński, 1963 (Lepidoptera, Pyraloidea, Crambinae) in Colombia, with descriptions of two new species
}

\section{El género Microcrambus Błeszyński, 1963 (Lepidoptera, Pyraloidea, Crambinae) en Colombia, con descripciones de dos especies nuevas}

\author{
Bernard Landry; Tommy Andriollo ${ }^{2}$
}

\begin{abstract}
${ }^{1}$ Research and Collections Officer, M.Sc., Ph.D. Muséum d'histoire naturelle. Geneva, Switzerland; e-mail: bernard.landry@ville-ge.ch; (DD https://orcid. org/0000-0002-6005-1067
\end{abstract}

${ }^{2}$ Ph.D. Muséum d'histoire naturelle. Geneva, Switzerland; e-mail: tommy.andriollo@ville-ge.ch; (D) https://orcid.org/0000-0003-3922-7475

How to cite: Landry, B.; Andriollo, T. 2020. A review of the genus Microcrambus Błeszyński, 1963 (Lepidoptera, Pyraloidea, Crambinae) in Colombia, with descriptions of two new species. Rev. U.D.C.A Act. \& Div. Cient. 23(2):e1628. http://doi.org/10.31910/rudca.v23. n2.2020.1628

Open access article published by Revista U.D.C.A Actualidad \& Divulgación Científica, under Creative Commons License CC BY-NC 4.0

Official publication of the Universidad de Ciencias Aplicadas y Ambientales U.D.C.A, University, Accredited as a High-Quality Institution by the Colombian Ministry of Education.

Received: April 14, 2020 Accepted: July 7, 2020 Edited by: Ingeborg Zenner de Polanía

\section{ABSTRACT}

Although consisting of 53 described species, the New World genus Microcrambus Błeszyński contains many more undescribed species. This study aims to bring a small contribution to the knowledge on the diversity of Microcrambus based on the fauna of Colombia. A literature review of the known fauna of the country was performed and specimens were collected at light in 2018. Five species are recorded for the first time from Colombia, including two new species ( $M$. arevaloi Landry and $M$. leticiensis Landry) from Leticia, Amazonas Department, described based on morphological and molecular data. The habitus of both sexes, as well as the genitalia are illustrated for the new species. The male genitalia of one Colombian specimen of Microcrambus elpenor Błeszyński are also illustrated as they were found to differ slightly with the drawing provided in the original description. A list of the eight species found to presently represent the known fauna of Microcrambus in Colombia is given, along with comments on their known distribution, including new country records.

Keywords: Pyralidae sensu lato; Taxonomy; Moths; Faunistics.

\section{RESUMEN}

Aunque ya consta de 53 especies, el género del Nuevo Mundo Microcrambus Błeszyński contiene muchas más especies sin describir. Este estudio tiene como objetivo realizar una pequeña contribución al conocimiento sobre la diversidad de Microcrambus, basado en la fauna de Colombia. Se realizó una revisión de la literatura de la fauna conocida del país y se recolectaron especímenes con trampas de luz, en 2018. Se registran cinco especies por primera vez para Colombia, incluidas dos nuevas ( $M$. arevaloi Landry y $M$. leticiensis Landry), de Leticia, Departamento de Amazonas, descritas con base a datos morfológicos y moleculares. El habitus de ambos sexos, así como los genitales, se ilustran para las nuevas especies. También, se ilustran los genitales masculinos de un espécimen colombiano de Microcrambus elpenor Błeszyński, ya que se halló que difieren ligeramente con el dibujo proporcionado en la descripción original. Se proporciona una lista de las ocho especies que, actualmente, representan la fauna conocida de Microcrambus en Colombia, junto con comentarios sobre sus distribuciones conocidas, incluidos nuevos registros para países.

Palabras clave: Pyralidae sensu lato; Taxonomía; Polillas; Faunística. 


\section{INTRODUCTION}

Microcrambus Błeszyński is the largest genus of Crambinae (Pyralidae sensu lato) in the New World, with 53 recognized species (Nuss et al. 2020), including the species formerly placed in Microcramboides Błeszyński, 1967 and Tortriculladia Błeszyński, 1967, following the results of the phylogenetic analyses of Léger et al. (2019). Except for Landry (1995), who provided a general review of the genus, and Munroe (1995) and Landry in Nuss et al. (2020), who listed all of the known species, there has been no taxonomic treatment on Microcrambus since the works of Błeszyński (1963, 1966, 1967) and Klots (1968). This may be due to the absence of species of economic importance in the genus (Landry, 1995) as well as the difficulty in tackling a large group of small species mostly resembling each other. Genus Microcrambus as well as half of its Neotropical species were described by Błeszyński $(1963,1967)$ and a synapomorphy for the genus, i.e. the ventro-apically produced phallus, was presented by Landry (1995). The Neotropical fauna of Microcrambus consists of 47 species, but only three species have been recorded from Colombia previously, as shown below. Based on the specimens collected in 2018, by BL in Colombia, two new species are described and three additional species are recorded here from Colombia for the first time.

\section{MATERIAL AND METHODS}

The specimens treated here were collected by BL in Colombia between July 18 and August 8, 2018 with the macro permit to collect insect specimens without commercial purposes of the "Universidad Nacional de Colombia". They were studied in the "Muséum d'histoire naturelle" in Geneva (MHNG) with the export permit issued by the "Asociación Nacional de Licencias AmbientalesANLA". Two localities were visited, i.e. "Parque Natural Chicaque" Cundinamarca Department, a few kilometres west of Bogotá, where sampling was performed between 2100 and $2250 \mathrm{~m}$, and forests around Leticia, in Amazonas Department, around $80 \mathrm{~m}$ in elevation. The specimens were attracted to light using Gunnar Brehm's fantastic Lepiled (Brehm, 2017) in a $2 \mathrm{~m}$ high tower of white gauze set usually on the ground, but one evening on a platform in a tree, at $35 \mathrm{~m}$ above ground level.

Specimens were dissected in 30\% ethanol following maceration in $\mathrm{KOH}$ at $60^{\circ} \mathrm{C}$ for one hour. Dissected parts were stored temporarily in lactic acid stained with Orange $G$, thus allowing their description in three dimensions. Mounting followed the method given by Landry (1995) except that xylol and Canada balsam were respectively replaced by Euparal essence and Euparal.

Photos were taken with a Leica M205, a Leica DFC425 camera and its associated imaging software. The photos were stacked using Zerene Stacker of Zerene Systems LLC and minimally modified using Adobe Photoshop Elements.

The labels of the holotypes are transcribed exactly, with vertical bars to represent changes of lines and missing letters of abbreviated words placed in square brackets. For the paratypes, the presentation of the label data is simplified, with the missing letters of abbreviated words placed in square brackets only on their first occurrence.

A total of 18 specimens were processed for DNA barcoding of the cytochrome $c$ oxidase I (COI) mitochondrial marker in the MHNG. DNA was extracted from specimens' legs using the commercial Chelex resin in deionised water containing $0.1 \mathrm{mg} / \mathrm{mL}$ proteinase K. A fragment of 658 bases of the COI gene was amplified using the versatile invertebrate primers [5'-AGT TCT AAT CAT AAR GAT ATY GG -3'] and [5'- TAA ACT TCA GGG TGA CCA AAA AAT CA -3'] (Nadler et al. 2006). PCR reactions were carried in a $20 \mu \mathrm{L}$ reaction volume, including $2 \mathrm{x} \mathrm{MyFi}$ Mix (containing the polymerase, dNTPs and salts), $4 \mu \mathrm{M}$ of each primer, and $4 \mu \mathrm{L}$ of extracted DNA. The thermocycling program followed BlascoCosta et al. (2016): it started with an initial denaturation at $95^{\circ} \mathrm{C}$ for $2 \mathrm{~min}$, followed by 40 cycles with $40 \mathrm{~s}$ denaturation at $94^{\circ} \mathrm{C}, 30 \mathrm{~s}$ annealing at $50^{\circ} \mathrm{C}$ and $45 \mathrm{~s}$ extension at $72^{\circ} \mathrm{C}$, and ended by a final extension for $5 \mathrm{~min}$ at $72^{\circ} \mathrm{C}$. PCR products were visually inspected by electrophoresis on an agarose gel and purified using Exo-SAP enzymes (Werle et al. 1994). Sequencing was carried for both strands with the same primers used for the amplification. Sequences were aligned and visually checked for errors using the software Geneious 8.1.9 (https://www.geneious.com). Assembled sequences and trace files, associated to collection data and pictures of the specimens, were deposited for all individuals on the BOLD platform (http:// www.boldsystems.org) under accession numbers LEPBL001-19 to LEPBL018-19. A taxon ID tree of all sequences available to us as of April 2020 was constructed using tools on BOLD. A total of 428 COI sequences of Microcrambus (including those deposited as Tortriculladia) were aligned using the BOLD amino-acid based aligner, and a neighbour-joining tree based on Kimura 2-parameter distances (K2P) was constructed (raw file deposited on Zenodo doi: https:/ / doi.org/10.5281/zenodo.3760713).

The following abbreviations are used: 'BL' for 'Bernard Landry', 'leg.' for 'legit', 'm' for 'meters', 'UNAB' for 'Universidad Nacional Agronomía Bogotá, Museo Entomológico de la Facultad de Ciencias Agrarias de la Universidad Nacional de Colombia', 'MHNG' for 'Muséum d'histoire naturelle, Genève, Switzerland', and 'ZMB' for 'Museum für Naturkunde Berlin, Leibniz-Institut für Evolutionsund Biodiversitaetsforschung, Berlin, Germany'.

The species collected in Colombia were identified with the original descriptions in addition to the publications of Błeszyński (1963, 1967) as well as with photos of the type specimens of all Neotropical species made by BL over the years during museum visits or following requests of photos to curators. In the case of $M$. expansellus (Zeller, 1877) (type locality: Panama, Chiriqui), only the illustrated original description is presently useful as the holotype, the single known specimen, deposited in the ZMB, is damaged beyond recognition, having lost its forewings, one hindwing, several legs, the labial palpi (as mentioned in the description), one antenna entirely and the other partly, and the whole abdomen. 


\section{RESULTS AND DISCUSSION}

\section{Taxonomic section:}

Microcrambus arevaloi Landry, sp. $\mathbf{n}$.

Material examined: $3 \hat{\jmath}, 3+$ from Colombia, Amazonas. Holotype: ${ }^{7}$, 'COLOMBIA, Amazonas, Leticia, Reserva Omagua, at LepiLED | 407'37'S, 6956'60’W | $115 \mathrm{~m}$ elev[ation]., on tree platform at | 35m above ground, 4.viii.2018 | leg. B. Landry, E. Ospina'; 'If selected as holotype | return to Museo | Entomológico, UNAB | Bogotá, Colombia'; 'Tgenitalia slide] BL 1861 సొ’; 'DNA voucher | Lepidoptera | B. Landry, nº 00005'; 'HOLOTYPE | Microcrambus arevaloi B. Landry'. Deposited in UNAB. Paratypes: 2 ते, 3 ․ 1 ते with same data as holotype except DNA voucher Lepidoptera B. Landry $n^{\circ} 00007 ; 1 q$ with same data as holotype except genitalia slide (and database) $n^{\circ}$ MHNG-ENTO 84603 우 and DNA voucher Lepidoptera B. Landry $n^{\circ} 00010 ; 1+$ with same data as holotype except DNA voucher Lepidoptera B. Landry $n^{\circ}$ 00009; 1 ते from Leticia, Univ[ersidad]. Nacional de Colombia, 4¹1'37'S, 6956'23”W, 80m elev[ation]., 24, 25, 31.vii.2018, at lights (B. Landry, H. Arévalo, F. Serna, J. De Prins), DNA voucher Lepidoptera B. Landry n ${ }^{\circ} 00006 ; 1$ †, Leticia, Reserva Natural La Manigua, 404’38”S, 6959’56”, 80m elev., 26, 27, 30.vii., 2.viii.2018, at lights (B. Landry, H. Arévalo, F. Serna, J. De Prins), DNA voucher Lepidoptera B. Landry $n^{\circ}$ 00008. Deposited in UNAB and MHNG.

Etymology: In honour of Helber Adrian Arévalo Maldonado, Ph.D. candidate at Universidad Nacional de Colombia, Bogotá, for his friendship, hospitality and for securing funds and collecting permits for BL in Colombia.

Diagnosis: Among the 40 known similarly coloured Microcrambus species, the forewing pattern can be distinguished by the reduction of the median markings to a few mostly faint spots seemingly aligned in two well separated diagonal lines running from the dorsal margin submedially towards the apex, the two distinct and clean dark brown subterminal lines bent towards the base before the costa and abutting a small but clear dark brown triangle on costa subapically, and a slightly darker band along the costa from the base until the subterminal lines (Figures 1a, b). In these aspects the species is similar to $M$. mather $\mathrm{K}$ lots, 1968, for example, but although the male valva of $M$. matheri also has a long costal arm, the latter is terminally rounded whereas that of $M$. arevaloi ends in a pair of spine-like projections. Microcrambus caracasellus Błeszyński, 1967 and M. discludellus (Möschler, 1890) also have a long free costal arm on the male valva but in both cases it is simple and terminally pointed. None of the other pale brown species of Microcrambus have a long and free costal arm of the valva as far as known, and, in species for which the male is unknown, the habitus lacks a pair of clean (without associated projections of the basal subterminal line) subterminal lines and well contrasted median markings.

CO1 barcode of holotype: 5'-GACATTATATTT'TATT'TTCGG AATCTGAGCAGGAATAGTAGGTACATCT'T'TAAGACT'T'T TAATTCGTGCTGAAT'TAGGTAATCCAGGATCT'T'TAAT'T GGTGATGACCAAATCTACAATACTAT'TGTCACAGCTCA TGCT'T"T"TAT"TATAAT'T"T"T"T"T"T"TATAGT'TATACCAAT"TATA
AT'TGGAGGAT'T'TGGAAAT'TGAT'TAGT'TCCT'T'TAATATTA GGAGCTCCAGACATAGCT'T'TCCCACGAATAAATAATATA AGAT'TTTGATTAT'TACCCCCT'TCT'T'TAACATTATTAATT'T CTAGAAGAATTGTAGAAAATGGAGCTGGGACAGGATG AACGGTT'TACCCCCCCCT'T'TCATCTAATATTGCTCATGG AGGAAGATCAGTAGATCT'TGCTAT'T'T'T'T'TCAT'TACAT'T'T AGCTGGAATT'TCT'TCAAT'T"T'TAGGAGCTATTAAT'T'TAT CACAACAATCAT'TAATATACGAATTAATAAT'T'TATCCT'T'T GATCAAATACCAT'TAT'T'TGT'T'TGATCAGTAGGAAT'TACT GCT'T"TACT'TT'TACT'TCTATCACTACCAGTT'TTAGCGGGA GCTATTACTATAC'T'T'TAACTGATCGAAAT'T'TAAATACCT CT'T'TCT'T'TGACCCTGCGGGAGGAGGAGATCCAAT'T'T'TA TATCAACAT'T'TAT'T'T-3'

Description: MALE ( $\mathrm{n}=3$ ) (Figure 1a). Head with frons slightly rounded although not projecting; vestiture short scaled and appressed except for porrect tuft of slightly longer scales laterally in front of antennal base, and fan of mostly short scales directed medially behind antenna and eye margin; colour mostly white to pale whitish cream with light greyish brown as a small patch at base of antenna frontomedially, in middle of frons, and on lateral tuft. Antenna light whitish cream on most of scape; apex of scape, pedicel, and flagellomeres greyish brown with few dirty white scales laterally on basal flagellomeres. Maxillary palpus white at base, followed by brown patch at base of longer, projecting apical scales mostly white with some whitish cream and greyish brown. Labial palpus white on two basal segments, brown (except medially) at apex of first segment dorsally, in middle of $2^{\text {nd }}$ segment, and at base of $3^{\text {rd }}$, pale whitish cream apically. Haustellum pale cream. Thorax mostly white to pale whitish cream, blackish brown at base of tegula and greyish brown to brown at tip of patagium and tegula, and tip of mesoscutellum. Forewing length: 5.5-5.75mm (holotype: 5.75mm); wingspan: $12.0-12.5 \mathrm{~mm}$ (holotype: $12.5 \mathrm{~mm}$ ). Wings with colour and pattern as illustrated (Figure 1 a) and diagnosed above. Prothoracic leg coxa and trochanter white to pale whitish cream; femur and tibia greyish brown dorsally, ventrally, including epiphysis, cream; tarsomeres darker, uniformly blackish brown. Mesothoracic leg coxa and trochanter as on foreleg; femur pale whitish cream with grey apex; tibia dorsally grey with whitish cream apex, ventrally whitish cream, with spurs darker, blackish brown; tarsomeres greyish brown to blackish brown, darkening toward distitarsus, with white to whitish cream apex on tarsomeres I-IV. Metathoracic leg coxa and trochanter as on foreleg; femur, tibia, and first tarsomere whitish cream; tarsomeres II-V as on foreleg. Abdomen whitish cream dorsally, white ventrally. Intersegmental membrane VII-VIII around genitalia set with thin long scales about as long as valva for longest of them.

Male genitalia $(\mathrm{n}=1)$ (Figures $2 \mathrm{a}, \mathrm{b})$. Uncus of moderate girth and length, abundantly setose dorsally and laterally, ending in short point bent downward. Gnathos arms and terminal section thin, latter slightly shorter than uncus, with apex bent downward. Tegumen of medium size, with dorsal connection slightly longer than uncus. Juxta a pair of rectangular plates shortly connected at base and subapically, scobinated ventromedially at base. Valva with cucullus narrow, narrowing from base of costal arm to narrowly rounded 
apex, with low medioventral hump before base of costal arm more thickly sclerotized and setose; costal arm thickly sclerotized, running along cucullus and almost reaching its tip, about equal in girth from base to more abundantly setose apex adorned with two spine-like projections: one very short pointing dorsally and other twice as long directed apicoventrally. Vinculum short, with more thickly sclerotized lateral and ventral margins, laterally expanded to about twice median length. Pseudosaccus small, pear shaped in dorsal view. Phallus short and rather bulky, about as long as valva, with digit-like coecum penis slightly longer and wider than posterior section of shaft, with short projecting subapical plate ventrally not reaching apex of shaft, latter with more thickly sclerotized narrow ventral wall set with minute spikes ventrally; vesica adorned with eight cornuti of medium size and large scobinated section apically in invaginated condition.

FEMALE (n=3) (Figure 1b): Forewing length: 5.5-6.5mm (wingspan: 12.0-14.0mm). Frenulum with 2 acanthae. Hindwing not darker than that of male. Abdominal segment VII about 1/3 longer than segment VI, slightly more thickly sclerotized distally and more densely scaled.

Female genitalia ( $\mathrm{n}=1$ ) (Figure 3a). Papillae anales lightly sclerotized, with modest setation and broad coverage of spinules, with posterior margin only lightly concave. Posterior apophyses straight, short, about as long as papillae anales and $2 / 3$ as long as their width, bulging medially along about $2 / 3$ of length, ending in thin point. Tergite VIII of medium width, enlarging lateroventrally into quadrangular sections about twice as long as dorsomedially, covered with spinules, and bent at right angle to form more thickly sclerotized dorsal plate of sterigma also spinulose and fused to even more thickly sclerotized ventrally disconnected ring around base of wide, lightly sclerotized protruding tube folded $3 \mathrm{X}$ upon itself and spinulose on distal $1 / 3$ ventrally and on distal $2 / 3$ dorsally; ostial margin of tube symmetrical, without ornamentation except for spinules; sclerotized tube internally more thickly sclerotized, long, reaching abdominal segment $\mathrm{V}$, slightly curved, with half-ringed sclerotized inception of ductus seminalis on right side at about $1 / 3$ from base of tube. Ductus bursae slightly shorter than internal section of tube, lightly scobinated near corpus bursae. Corpus bursae circular, small, about as long as ductus bursae, lightly scobinated all over; unique signum near proximal end on right side, a wide scobinated folded plate about $1 / 3$ as wide as corpus bursae and with fold reaching inside corpus bursae to about $1 / 4$ of its width.

Biology: Unknown except that adults come to light and fly low above the ground as well as at $35 \mathrm{~m}$ above, in the tree canopy.

Distribution: Presently known only from the Amazonas Department of Colombia, near its capital, Leticia.

Remarks: The six available specimens were sampled for their DNA and yielded full sequences of the COI barcode. In the neighbourjoining tree, the sequences of $M$. arevaloi cluster with a group of species including M. jolas Błeszyński, 1967, M. elegans (Clemens, 1860) and M. polingi (Kearfott, 1908) with a minimal K2P divergence of
$8.4 \%$. Four of the specimens (LEPBL005, 007, 008, 009) have the same barcode sequence, one specimen (LEPBL006) diverges by one transition (K2P 0.2\%) from the foursome and specimen LEPBL010 diverges by three other transitions (K2P $0.5 \%$ ) from the foursome. The six specimens available are each missing one-two metathoracic legs, retrieved for DNA barcoding. The colouration of the abdomen is based only on the undissected paratypes as the holotype had been dissected prior to description. Four of the six specimens were collected on a platform at $35 \mathrm{~m}$ above ground and during about two hours, beginning at sunset, more than 200 species of moths were observed or collected there, the most fruitful collecting event of the 12 performed at Leticia by BL in 2018.

\section{Microcrambus leticiensis Landry, sp. $\mathbf{n}$.}

Material examined: $1 \hat{\jmath}, 1$ . Holotype: $\hat{\jmath}$, 'COLOMBIA, Amazonas, Leticia | Reserva Natural La Manigua | at lights, $80 \mathrm{~m}$ elev[ation]., 404’38”S | 6959'56”'W, 26, 27, 30.vii., | 2.viii.2018, leg. B. Landry, H. | Arévalo, F. Serna, J. De Prins'; 'If selected as holotype | return to Museo | Entomológico, UNAB | Bogotá, Colombia'; ' 'genitalia slide] BL 1860 స’"; 'DNA voucher | Lepidoptera | B. Landry, n' 000011'; 'HOLOTYPE | Microcrambus | leticiensis | B. Landry'. Deposited in UNAB.

Paratype: 1 q. Same data as holotype except genitalia slide (and database) $n^{\circ}$ MHNG-ENTO $84602+9$ and DNA voucher Lepidoptera B. Landry $n^{\circ}$ 00012. Deposited in MHNG.

Etymology: Derived from the name of the type locality, the municipality of Leticia, Colombia, situated alongside the Amazon River.

Diagnosis: Among the 40 described species of Microcrambus with a pale brown or greyish brown background colour, this one can be recognized by the generally darker greyish brown colour, appearing mouse grey, with darker markings in a pair of spots submedially on dorsal half, but not touching the dorsal margin, a short, submedian costal bar directed toward the tornus, a median line from the middle of the dorsal margin, directed towards the apex and veering back at right angle towards the costa and reaching it, a straight and clean (without associated projections) subterminal black line slightly wider on costal half followed by a paler line, a finer dark line reaching the tornus, and a white section with contrasting dark brown spots between veins on the terminal margin. In male genitalia (Figures 2c, d), this species is most similar to M. bellargus Błeszyński, 1967 but with the uncus shorter than the gnathos as opposed to equal in length in M. bellargus, the sclerotized valval costa ending in two separate projections as opposed to one in $M$. bellargus, the absence of a short rounded projection medially on the sacculus subapically, the shorter and less slender phallus, and the vesica with a row of six short spine-like cornuti along with several smaller, similarly shaped cornuti mostly ventrally toward the apex of the shaft in its invaginated state, as opposed to the absence of cornuti on the vesica of M. bellargus. In female genitalia (Figure 3b) this species is very similar to M. castrellus (Schaus, 1922), known from the single female holotype, but the internal tube of the antrum is shorter and 
apparently not folding onto itself completely in $M$. castrellus and the ductus bursae is shorter, i.e. only $1.5 \mathrm{X}$ the length of the corpus bursae whereas is it about 2.2 times this length in $M$. leticiensis. In habitus the holotype of $M$. castrellus differs more conspicuously than in genitalia, with a paler ground colour with faint warmerbrown (described as sayal brown) markings, including an incomplete basal subterminal line made of several fine striated lines without a contrastingly paler line before the second subterminal line.

CO1 barcode of holotype: 5'-AACT'TATATT'T'TATT'TTTGG AAT'T'TGAGCAGGAATAATCGGAACT'TCT'T'TAAGT'TAT'T AATTCGTGCTGAATTAGGTAACCCTGGAT'T'T'TAATTGG AGATGATCAAAT'T'TATAATACTATTGT'TACAGCTCATGC T'T'TATTATAAT'T'T'T'T'T'TATAGTAATACCAATTATAAT'T GGAGGT'T'TGGAAAT'TGAT'TAGT'TCCT'T'TAATATTAGG AGCCCCAGATATAGCT'TCCCACGAATAAATAATATAAG AT'T'T'TAT'TACTCCCCCCATCTCTGACTCTAT'TAAT'T'TCT AGAAGAATTGTCGAAAATGGAGCAGGAACAGGATGAA CAGTT'TACCCCCCACT'T'TCATCTAATATTGCTCATGGAG GTAGATCAGT'TGATCTAGCCAT'T'T'T'TCCC'TCACT'TAG CTGGGAT'T'TCT'TCAATCT'TAGGAGCCAT'TAAT'T'T'TATTAC TACAATTATTAATATACGAATTAATGGATTAATAT'T'TGAC CAAATACCT'T'TAT'T'TGT'T'TGATCTGTAGGAAT'TACTGCT'T TAT'TACTAT'TAT'TATCT'T'TACCTGTAT'TAGCGGGAGCTAT TACTATACT'T'T'TAACAGATCGAAAT'T'TAAATACT'TCT'T'TCT T'TGACCCTGCTGGAGGAGGAGATCCAAT'T'T'TATATCAAC AT'TTAT'T'T-3'

Description: MALE ( $\mathrm{n}=1$ ) (Figure 1c). Head with frons rounded, not projected; vestiture partly missing in unique specimen, dirty white to greyish brown, darker greyish brown at eye margin posteriorly and dorsomedially projecting fan behind antenna. Antenna dark greyish brown with dirty white ventrally on scape and pedicel. Maxillary palpus greyish brown with dirty white apically. Labial palpus mostly greyish brown laterally, darker on first segment, white medially, dirty white at apex of second and third segments. Haustellum dark greyish brown dorsally, dirty white laterally. Thorax with patagium scales greyish brown medially, dirty white laterally; tegula pale greyish brown (but base not visible); tip of mesoscutellum dark brown; metascutum white with pale greyish brown medially. Wings with colour and pattern as illustrated (Figure 1c) and diagnosed above. Forewing length: $5.0 \mathrm{~mm}$ (wingspan: $11.0 \mathrm{~mm}$ ). Prothoracic leg coxa and trochanter dirty white; femur pale greyish brown ventrally, not hidden dorsally; tibia and tarsi dark greyish brown. Mesothoracic leg coxa and trochanter dirty white; femur dirty white; tibia greyish brown, darker at base and on spurs; basal tarsal segment pale greyish brown; tarsal segments II-IV dark greyish brown with pale greyish brown tip; distitarsus all dark greyish brown. Intersegmental membrane VII-VIII medioventrally devoid of scales but with sclerotized finger-tip shaped plate about as long as pseudosaccus; lateroventrally with narrow scaled area enlarging, folded, with narrow scales of medium length; laterally with enlarged, rounded scaled area with long hair-like scales.

Male genitalia $(n=1)$ (Figure 2c, d). Uncus of medium girth and length, moderately setose, apically narrowly rounded. Gnathos narrow, slightly longer than uncus, with distal section gently curving downward, with short apical hook. Tegumen of medium size, with pedunculi medially about as wide as dorsal connection. Juxta of medium size, heater-shield shaped with short and rounded apicolateral projections. Valva with thickly sclerotized sacculus, without ornamentation but with coat of short, stiff setae medially; cucullus directed upward at right angle, short, with pointed apex; costa of valva thickly sclerotized, ending before cucullus in pair of short hooks: ventral directed medially at right angle, dorsal directed dorsomedially at about $50^{\circ}$. Vinculum quadrangular, with wide, straight basal margin. Pseudosaccus long and thin, bananashaped, concave dorsally. Phallus of medium length and girth, as long as vinculum+valva, slightly down-curved, with short coecum penis, with ventral margin forming thin point shortly produced at apex; vesica with six short spine-like cornuti, increasing in size towards apex in invaginated condition, also with several smaller, similarly shaped cornuti mostly ventrally toward apex of shaft in its invaginated state, and wide coverage of scobination.

FEMALE ( $\mathrm{n}=1$ ) (Figure 1d): Forewing length: 5.5mm (wingspan: $12.0 \mathrm{~mm}$ ). Frenulum with 2 acanthae. Hindwing not darker than that of male. Tergite VII longer than VI, with posterior half more thickly sclerotized, apically set with more robust scales of mostly medium length and variable width, the longer the thinner, and slightly curved ventrally towards their apices.

Female genitalia $(n=1)$ (Figure $3 b)$. Papillae anales triangular with almost straight posterior margin, with moderate setation and wide coverage of spinules; posterior apophyses straight and short, about as long as papillae anales and half as long as their width. Tergite VIII a very narrow band expanding lateroventrally into pearshaped plates with medioventral connection about half as wide as widest section. Sterigma a pair of medioventrally unconnected lateroventral oblong plates of medium size at right angle from longitudinal plane of abdomen (thus directed ventrally); plates medially abutting diagonally constricted thickly sclerotized tube expanding into asymmetrical exterior section with left side straight and right side bulging at base; ostial margin of tube symmetrical, without ornamentation or spinules; tubular internal section of sterigma narrow, about half as wide as external section, curving back onto itself at $180^{\circ}$ and narrowing to about $1 / 3$ basal section distally. Ductus seminalis at distal end of sclerotized tube, at base of ductus bursae. Ductus bursae thin, only slightly and evenly expanding before reaching corpus bursae, and long, reaching apical margin of third abdominal segment and $2.2 \mathrm{X}$ length of corpus bursae, scobinated lightly all along. Corpus bursae small, circular, lightly scobinated all over; unique signum near proximal end on right side, a folded circular plate with thick scobination.

Biology: Unknown except that adults come to light and fly in July and August.

Distribution: Colombia, Amazonas Department, around Leticia.

Remarks: The two specimens were sampled for their DNA and both yielded the same full sequences of the COI barcode. In the 
neighbour-joining tree, the sequences of $M$. leticiensis cluster with a sequence of a specimen identified as Microcrambus croesus Błeszyński, 1967, from Texas with a divergence of $9.0 \%$. The two specimens available are each missing both metathoracic legs, retrieved for DNA barcoding. The colouration of the abdomen was not recorded as both specimens had been dissected prior to description.

\section{Toward a list of the species of Microcrambus Błeszyński in Colombia}

1. Microcrambus arevaloi, sp. n. described above from Amazonas, Leticia.

2. Microcrambus discludellus (Möschler, 1890). Occurrence based on type locality (Colombia, Tolima, Honda) of Crambus micralis Hampson, 1919, a synonym of $M$. discludellus, which was itself described from Puerto Rico. Crambus domingellus Schaus, 1922, another synonym, was described from Dominican Republic. The species is distributed also in the USA (Florida, South Carolina) (Moth Photographers Group, 2020).

3. Microcrambus elpenor Błeszyński, 1967. Six male and two female specimens were collected around Leticia by BL in 2018. Three of the males and one female were barcoded and show the exact same barcodes. The dissected female have genitalia matching perfectly with the illustration provided by Błeszyński (1967, figure 59) whereas a dissected male, illustrated here (Figures $2 \mathrm{e}, \mathrm{f})$ have genitalia that differ slightly from the illustration provided by Błeszyński (1967, figure 63) in the slightly shorter and wider uncus, the slightly longer dorsal projection of the valva and the slightly shorter and wider valva with the terminal section directed dorsally at an angle closer to $90^{\circ}$. Described from Chiapas, Mexico (type locality) as well as Guyana and Trinidad (Trinidad and Tobago), the species is also known to occur in Brazil, Bahía (Camacan and Porto Seguro) (specimens collected by BL and Vitor Becker and identified by BL).

4. Microcrambus immunellus (Zeller, 1872). Occurrence based on type locality (Colombia, Cundinamarca, near Ubaque). Records of other localities by Zeller $(1877,1881)$ are preferable to other species according to Błeszyński (1967). Druce (1896: 290) mentions it from Costa Rica, although this record has not been validated with dissections.

5. Microcrambus jolas Błeszyński, 1967. Based on two males collected around Leticia by BL in 2018. One dissected male has genitalia matching perfectly with the illustration provided by Błeszyński (1967, figure 72). Described from Mexico, Chiapas, the species is also known to occur in south west Nicaragua from specimens collected by BL that show a $2.8-3.5 \%$ divergence in $\mathrm{CO} 1$ barcodes from the two Colombian specimens.

6. Microcrambus leticiensis, sp. n. described above from Amazonas, Leticia.

7. Microcrambus mercury Błeszyński, 1963. Occurrence based on type locality (Colombia, Chocó Department, Condoto). Described from two males, this species has not been reported since.

8. Microcrambus cf. mixena (Błeszyński, 1967). This record is based on the two females collected by BL around Leticia in 2018. Both were barcoded and belong to the same BIN (Barcode Index Number) as three specimens collected in French Guiana
(BOLD: AAU7498). These three specimens were borrowed from the "Muséum national d'histoire naturelle" (Paris, France) and one of them, a male, was dissected. The genitalia of this male match reasonably well with the illustration provided by Błeszyński (1967, fig. 42) for his M. mixena, a species described from Peru, near Aguaytia, at $400 \mathrm{~m}$ in elevation, on the Eastern slope of the Andes, about $825 \mathrm{~km}$ from Leticia as the crow flies. A photo of the unique holotype of $M$. mixena, deposited in the Canadian National Collection of Insects, Ottawa, Ontario, Canada, is also a good match in habitus with the Leticia specimens although three other species are similar in habitus. A study of the genitalia preparation of the holotype of $M$. mixena and a more in-depth taxonomic revision of this group of six species formerly placed in Tortriculladia Błeszyński, will be necessary to confirm the identity of the Colombian specimens at hand.

\section{Final remarks}

The Colombian fauna of Microcrambus is shown here to consist of eight recorded species. This is clearly an incomplete assessment of this fauna given the large number of species of Microcrambus and paucity of previous collecting efforts on micro moths in Colombia. Specimens of Microcrambus from Colombia probably exist in some natural history collections, but they were not requested here for the purposes of this project. Specimens in the field should be looked for in the lowlands especially, as the genus doesn't appear to be common at high elevations as it was not recorded during BL's collecting efforts at Parque Natural Chicaque (2100-2250m) nor in the páramo of the country by Wolfram Mey (ZMB), in 2017.

Acknowledgements: We wish to thank Helber Adrian Arévalo Maldonado and his Ph.D. advisor Francisco Serna of the Universidad Nacional de Colombia, Bogotá for their hospitality, friendship, logistical support and export permit (ANLA $\mathrm{n}^{\circ}$ 01292, 2018) in order for BL to achieve successful pyraloid moth collecting in Colombia in 2018, as well as to Colciencias and the project "Reconocimiento de Insectos de importancia agronómica asociados al agroecosistema Cacaotero de la Amazonía Colombiana" for the financial support. BL also wishes to thank Daniela Cubillos Cañizares, Javier Martinez, Esau Ospina, and the other students of Francisco's lab for companionship and help in the field, as well as Oscar Puentes and his team for logistical support in Leticia. BL is further grateful to Willy Camelo of Parque Natural Chicaque for access and the permission to collect moth specimens. We are grateful to Isabel Blasco-Costa for providing the sequencing lab space and reagents used in our study. We are deeply grateful to Michael Shaffer (deceased), Natural History Museum, London, U.K., Théo Léger, ZMB, Rodolphe Rougerie, "Muséum national d'histoire naturelle", Paris, France, and M. Alma Solis, National Museum of Natural History, Washington, D.C., USA and for providing access to specimens or photos of type specimens. We are further grateful to Florence Marteau (MHNG) for producing the plates and Philippe Wagneur (MHNG) for image enhancement. Last but not least we thank the reviewers and editorial staff of the journal for their constructive comments and corrections. 


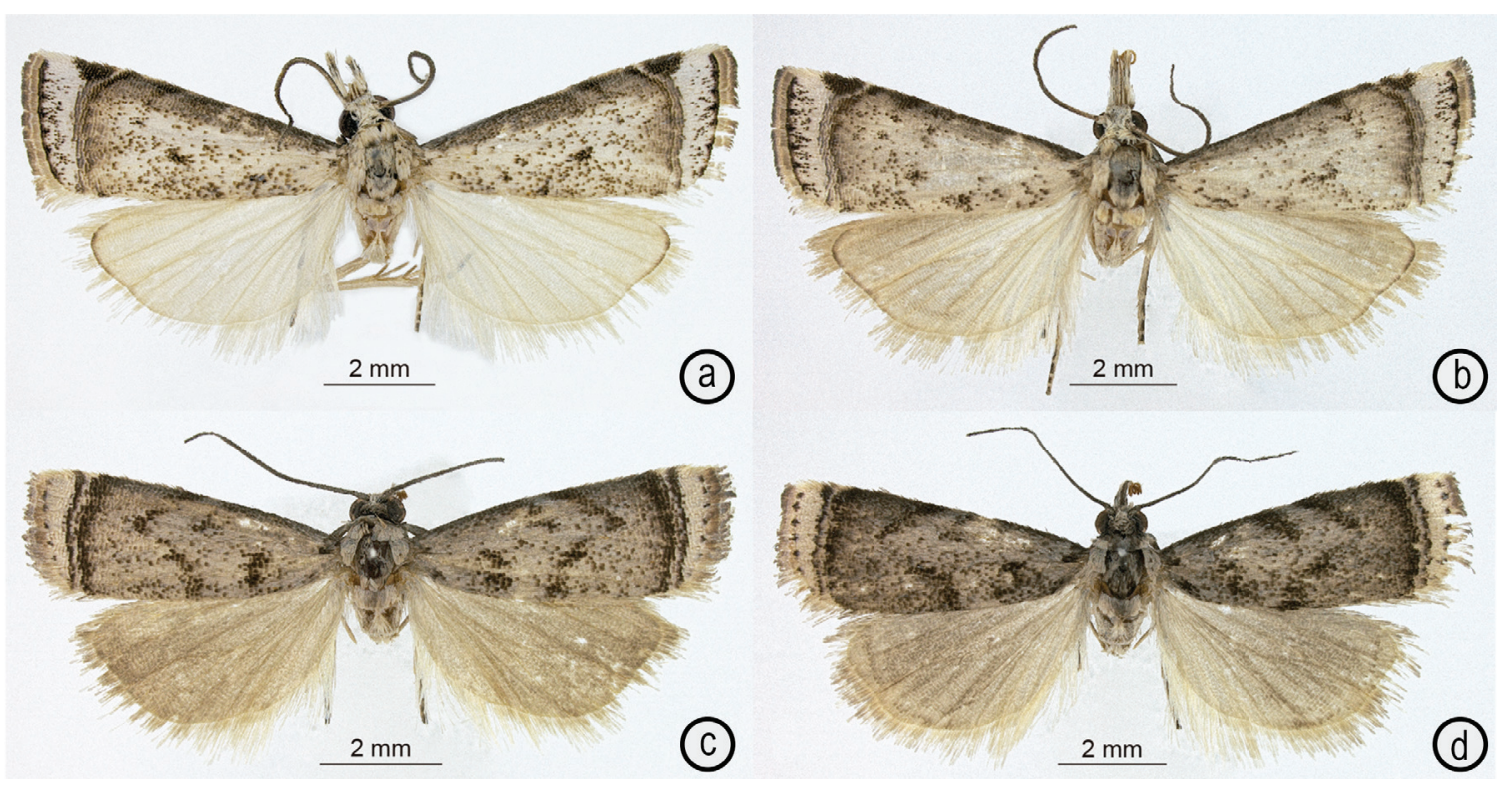

Figure 1. Specimens of Microcrambus species. (a-b) Microcrambus arevaloi; a. Male holotype, UNAB; b. Largest female paratype, MHNG. (c-d) Microcrambus leticiensis; c. Male holotype, UNAB; d. Female paratype, MHNG.
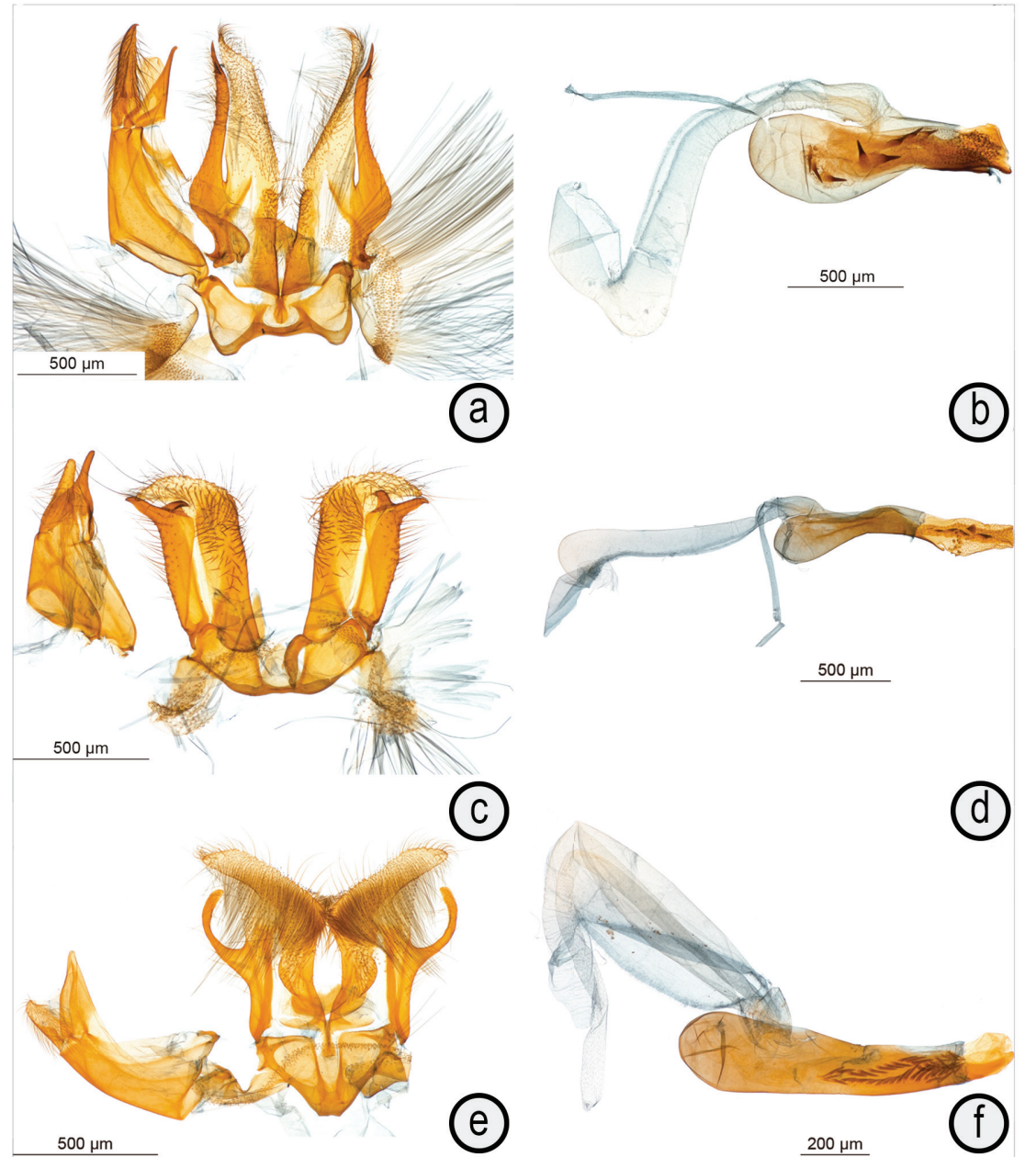

(a)

(b)

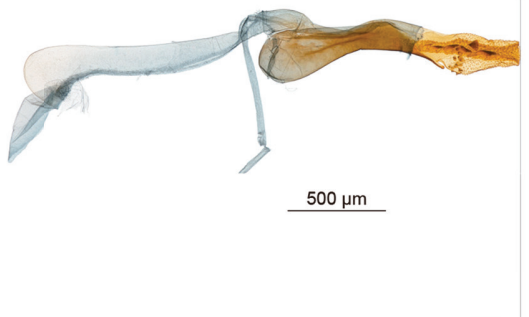

(C)

(d)

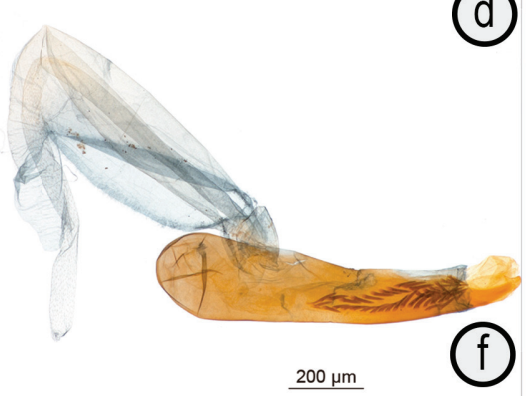

Figure 2. Male genitalia of Microcrambus species, left showing the genitalia without phallus and right the phallus; a and b. Microcrambus arevaloi holotype; c and d. Microcrambus leticiensis holotype; e and f. Microcrambus elpenor, slide BL 1858, Leticia, Reserva Natural La Manigua. 

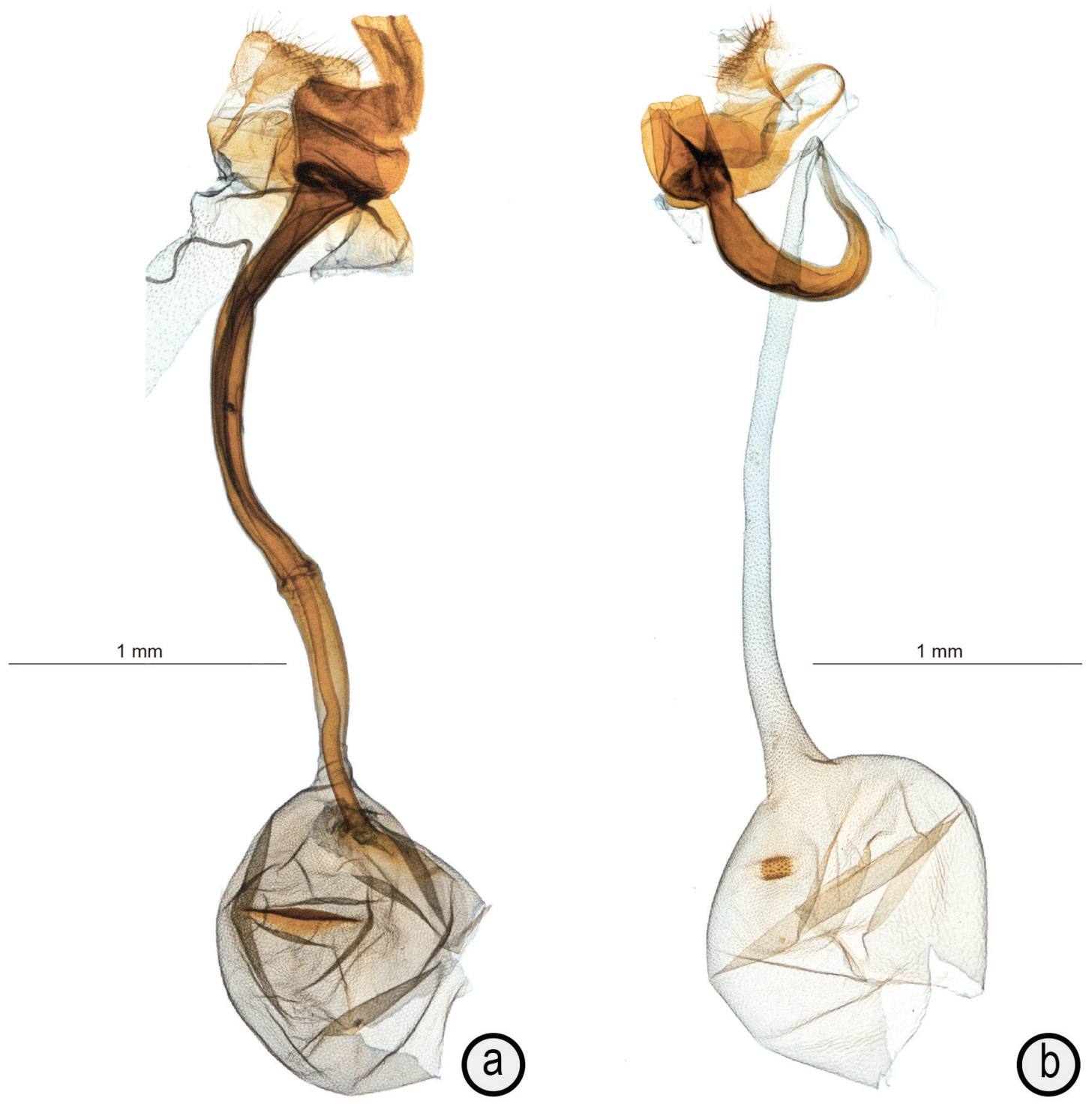

Figure 3. Female genitalia of Microcrambus species. A) Microcrambus arevaloi paratype, with tubular section of spermatophore left inside ductus bursae, slide MHNG-ENTO- 84603; b) Microcrambus leticiensis paratype, slide MHNG-ENTO-84602.

Conflict of interests: The manuscript was prepared and revised by both authors who declare the absence of any conflict which could put the validity of the presented results at risk.

\section{REFERENCES}

1. BLASCO-COSTA, I.; POULIN, R.; PRESSWELL, B. 2016. Species of Apatemon Szidat, 1928 and Australapatemon Sudarikov, 1959 (Trematoda: Strigeidae) from New Zealand: linking and characterising life cycle stages with morphology and molecules. Parasitology Research. 115:271-289. https://doi.org/10.1007/s00436-015-4744-0
2. BŁESZYNSSKI, S. 1963. Studies on the Crambidae (Lepidoptera). Part 41. On some tropical Crambidae with descriptions of new genera and species. Acta Zoologica Cracoviensia (Poland). 8:133-181.

3. BŁESZYŃSKI, S. 1966. Studies on the Crambinae (Lepidoptera). Part 43. Further taxonomic notes on some tropical species. Acta Zoologica Cracoviensia (Poland). 11:451-497.

4. BŁESZYNSKI, S. 1967. Studies on the Crambinae (Lepidoptera). Part 44. New Neotropical genera and species. Preliminary check-list of Neotropical Crambinae. Acta Zoologica Cracoviensia (Poland). 12(5):39-110. 
5. BREHM, G. 2017. A new LED lamp for the collection of nocturnal Lepidoptera and a spectral comparison of light-trapping lamps. Nota Lepidopterologica (Germany). 40(1):87-108.

https://doi.org/10.3897/nl.40.11887

6. CLEMENS, B. 1860. Contributions to American lepidopterology. Proc. Academy of Natural Sciences of Philadelphia (United States of America). 12:4-15, 156-174, 203-221, 345-362, 522-547.

7. DRUCE, H. 1881-1900. Insecta. Lepidoptera-Heterocera. In: Godman, F. D.; Salvin, O. (eds) Biologia CentraliAmericana. vol. 2. Taylor \& Francis (London). pp.1-622.

8. DRUCE, H. 1881-1900. Insecta. Lepidoptera-Heterocera. In: Godman, F. D.; Salvin, O. (eds) Biologia CentraliAmericana. vol. 3. Taylor \& Francis (London). pp.1-101.

9. HAMPSON, G.F. 1919. Descriptions of new Pyralidae of the subfamilies Crambinae and Siginae. Annals and Magazine of Natural History, including Zoology, Botany and Geology (United Kingdom) 3(ser. 9):275-292, 437-457, 533-547.

10. KEARFOTT, W.D. 1908. Descriptions of new species of North American crambid moths. Proc. United States National Museum. 35(1649):367-393.

11. KLOTS, A.B. 1968. The North American Microcrambus (Lepidoptera: Pyralididae [sic]). J. New York Ent. Soc. (United States of America). 76:9-21.

12. LANDRY, B. 1995. A phylogenetic analysis of the major lineages of the Crambinae and of the genera of Crambini of North America (Lepidoptera: Pyralidae). Memoirs on Entomology, International, Gainesville (United States of America). Vol. 1. 245p.

13. LÉGER, T.; LANDRY, B.; NUSS, M. 2019. Phylogeny, character evolution and tribal classification in Crambinae and Scopariinae (Lepidoptera, Crambidae). Systematic Entomology (United Kingdom). 44(4):757-776. https://doi.org/10.1111/syen.12353

14. MÖSCHLER, H.B. 1890. Die Lepidopteren-Fauna der Insel Portorico. Abhandlungen herausgegeben von der Senckenbergischen Naturforschenden Gesellschaft (Germany). 16:69-360.
15. MOTH PHOTOGRAPHERS GROUP. 2020. http:// mothphotographersgroup.msstate.edu (Accessed 12/04/2020).

16. MUNROE, E.G. 1995. Crambidae (Crambinae, Schoenobiinae, Cybalomiinae, Linostinae, Glaphyriinae, Dichogaminae, Scopariinae, Musotiminae, Midilinae, Nymphulinae, Odontiinae, Evergestinae, Pyraustinae). p.34-79. In: Heppner, J.B. (ed.) Atlas of Neotropical Lepidoptera. Checklist: Part 2. Hyblaeoidea - Pyraloidea - Tortricoidea 3. Association for Tropical Lepidoptera \& Scientific Publishers (Gainesville).

17. NADLER, S.A.; BOLOTIN, E.; STOCK, S.P. 2006 Phylogenetic relationships of Steinernema Travassos, 1927 (Nematoda: Cephalobine: Steinernematidae) based on nuclear, mitochondrial and morphological data. Systematic Parasitology. 63:161-181.

18. NUSS, M.; LANDRY, B.; MALLY, R.; VEGLIANTE, F.; TRÄNKNER, A.; BAUER, F.; HAYDEN, J.; SEGERER, A.; SCHOUTEN, R.; LI, H.; TROFIMOVA, T.; SOLIS, M.A.; DE PRINS, J.; SPEIDEL, W. 2003-2020. Global Information System on Pyraloidea. World Wide Web electronic publication: www.pyraloidea.org (Accessed 01/04/2020).

19. SCHAUS, W. 1922. New species of Pyralidae of the subfamily Crambinae from tropical America. Proc. Ent. Soc. Washington (United States of America). 24:127-145.

20. WERLE, E.; SCHNEIDER, C.; RENNER, M.; VOLKER, M.; FIEHN, W. 1994. Convenient single-step, one tube purification of PCR products for direct sequencing. Nucleic Acids Research (United Kingdom). 22:4354-4355.

21. ZELLER, P.C. 1872. Columbianer Arten der Gattungen Chilo, Crambus et Scoparia. Stettiner Entomologische Zeitung (Germany). 33:463-481.

22. ZELLER, P.C. 1877. Exotische Microlepidoptera. Horae Societatis Entomologicae Rossicae (Russia). 13:1-491.

23. ZELLER, P.C. 1881. Columbische Chiloniden, Crambiden und Phycideen. Horae Societatis Entomologicae Rossicae (Russia). 16:154-256. 